\title{
Bảy dấu hiệu cảnh báo cần lưu ý để ổn định nền tài chính quốc gia
}

\author{
Phạm Minh Chính \& Vương Quân Hoàng
}

May 15, 2008

Tạp Chí Cộng Sản

No. 787 (5-2008)

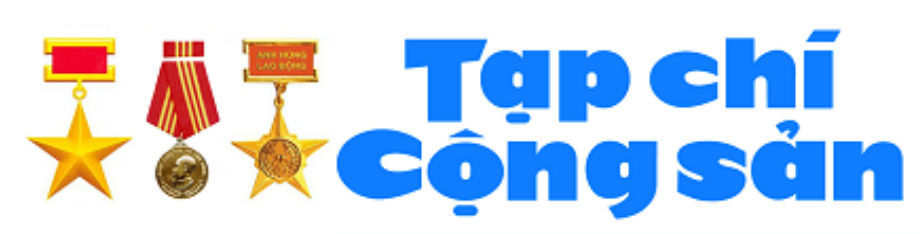

http://dulieu.tapchicongsan.org.vn/Home/PrintStory.aspx?distribution=1420\&print=true

\section{Tóm tắt:}

Nếu nền kinh tế quốc gia là một cơ thể sống, thì hệ thống tài chính là cơ chế tạo, cung cấp và lưu thông máu tới từng tế bào, bộ phận. Thiếu hay thừa đều phát sinh các vấn đề cần giải quyết. Với quá trình chuyển đổi kinh tế và hội nhập quốc tế mạnh mẽ, liên tục giám sát, kịp thời dự đoán sát thực các dấu hiệu và biến động của thị trường để từ đó xây dựng chính sách điều tiết thị trường tài chính và toàn bộ nền kinh tế một cách hợp lý là việc làm cần thiết bảo đảm tăng trưởng kinh tế bền vững, đúng định hướng. Đối với nền tài chính của Việt Nam, hiện đang tồn tại bảy dấu hiệu cảnh báo cần được các nhà nghiên cứu và hoạch định chính sách quan tâm.

https://tapchicongsan.org.vn/web/guest/nghien-cu/-/2018/2640/muc-luc-tap-chi--cong-sanso--787-\%285-2008\%29.aspx 


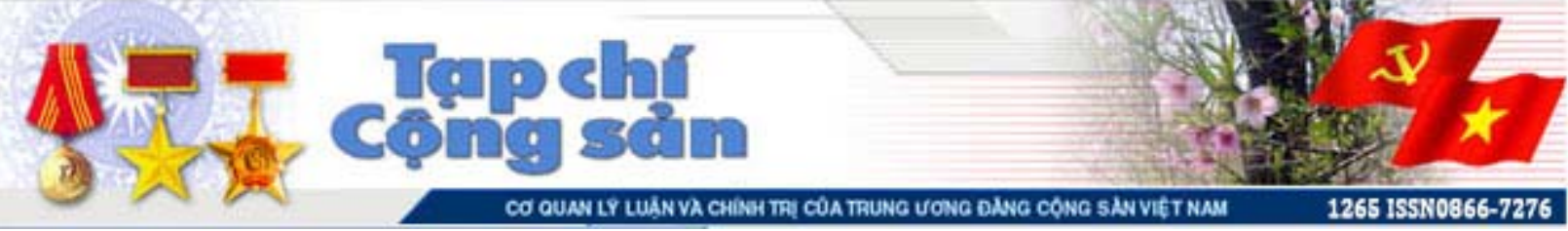

\section{Bảy dấu hiệu cảnh báo cần lưu ý để ổn định nền tài chính quốc gia}

$15 / 5 / 2008$ 10:15

Nếu nền kinh tế quốc gia là một cơ thể sống, thì hệ thống tài chính là cơ chế tạo, cung cấp và lưu thông máu tới từng tế bào, bộ phận. Thiếu hay thừa đều phát sinh các vấn đề cần giải quyết. Với quá trình chuyển đổi kinh tế và hội nhập quốc tế mạnh mẽ, liên tục giám sát, kịp thời dụ̣ đoán sát thực các dấu hiệu và biến động của thị trường để từ đó xây dựng chính sách điều tiết thị trường tài chính và toàn bộ nền kinh tế một cách hợp lý là việc làm cần thiết bảo đảm tăng trưởng kinh tế bền vững, đúng định hướng. Đối với nền tài chính của Việt Nam, hiện đang tồn tại bảy dấu hiệu cảnh báo cần được các nhà nghiên cứu và hoạch định chính sách quan tâm.

\section{1 - Giảm dần tỷ lệ sở hữu nhà nước trong hệ thống tài chính}

Quyền kiểm soát của Nhà nước đối với các hoạt động kinh tế vốn được xem như yếu tố có tính nhạy cảm. Nhưng những biến đổi của nền kinh tế trong xu thế hội nhập ngày càng sâu sắc và áp lực cạnh tranh ngày càng lớn đang tạo ra một sắc thái mới, đó chính là tỷ lệ giảm dần của sở hữu nhà nước trong các tổ chức kinh tế. Không chỉ cổ phần hóa các doanh nghiệp sản xuất, thương mại quốc doanh, trong lĩnh vực rất trọng yếu là tín dụng - ngân hàng cũng diễn ra xu thế này.

Trước năm 1986, Việt Nam theo mô hình kinh tế kế hoạch hóa tập trung, mọi giao dịch tài chính (chính thức) đều do Nhà nước thực hiện thông qua Ngân hàng Nhà nước. Ngân hàng Nhà nước vận hành theo hệ thống một cấp (Ngân hàng Trung ương đảm nhiệm luôn chức năng của các ngân hàng thương mại), thuộc sở hữu nhà nước 100\% và do Nhà nước trực tiếp quản lý, kiểm soát).

Đến năm 1988, chức năng kinh doanh ngân hàng được tách khỏi Ngân hàng Nhà nước để giao cho các ngân hàng chuyên doanh. Hệ thống ngân hàng hai cấp được hình thành, tạo nên các chuyển biến về tự do tài chính, là điều kiện cho các hình thức sở hữu khác trong hệ thống tài chính phát triển. Cùng năm, Nhà nước ban hành tạm thời các thể lệ tín dụng, cho phép tất cả các tổ chức kinh tế được vay tiền và huy động vốn từ công chúng (Quyết định số 18/NH-QĐ và 19/NH-QĐ ngày 27-4-1988). Thị trường tài chính trong nước được tự do hóa gần như hoàn toàn.

Sau đó, số tổ chức tín dụng tăng rất nhanh. Năm 1989, trên toàn quốc đạt con số 7.180 quỹ và hợp tác xã tín dụng. Tuy nhiên, cuối năm 1989, hàng loạt các tổ chức tín dụng đổ bể và gây ra khủng hoảng tài chính. Sau sự kiện nhiều dư chấn này, hai pháp lệnh về ngân hàng được đưa ra trong năm 1990, nhằm củng cố hệ thống ngân hàng hai cấp, bắt đầu hình thành các công cụ quản lý và điều hành tiền tệ. Tỷ trọng tài sản tại các ngân hàng quốc doanh trong tổng tài sản của hệ thống ngân hàng thương mại kể từ đây cũng giảm dần. Tỷ lệ này năm 1994 là 89\%, đến năm 1998 giảm xuống 
còn $82 \%$; năm 2003 còn $74,6 \%$; năm 2005 còn $71,5 \%$ và năm 2006 còn $62,5 \%$.

Từ năm 2007, hệ thống tài chính cũng được mở cửa theo thỏa thuận gia nhập WTO. Các nhà đầu tư nước ngoài được phép mở ngân hàng nước ngoài tại Việt Nam từ ngày 1-4-2007. Các ngân hàng và tổ chức đầu tư nước ngoài đang tiến hành quá trình "thâu tóm cổ phần" các ngân hàng thương mại cổ phần (NHTMCP) Việt Nam. Giai đoạn 2007 - 2008, hoạt động thâu tóm và sáp nhập (M\&A) của các đối tác nước ngoài với tổ chức tài chính Việt Nam tiếp tục phát triển sang khu vực tài chính chứng khoán. Morgan Stanley nắm $10 \%$ cổ phần Công ty Tài chính Dầu khí (PVFC) và $48,33 \%$ Công ty chứng khoán Hướng Việt. Franklin Templeton Investment mua 49\% Công ty cổ phần (CTCP) Quản lý quỹ Đầu tư Vietcombank. CTCP Chứng khoán Sài Gòn (SSI) - công ty chứng khoán lớn nhất Việt Nam, có tỷ lệ sở hữu thuộc cổ đông nước ngoài là $21,78 \%$ (tính tới ngày 24-7-2007), trong đó cổ đông tổ chức chiếm 20,93\% với các tên tuổi như: Japan Asia Investment Co. Ltd. và Ngân hàng ANZ. Vì vậy, dự báo tỷ lệ sở hữu nhà nước trong hệ thống tín dụng - ngân hàng sẽ còn tiếp tục giảm.

\section{2 - Gian lận tài chính quy mô lớn và sử dụng công nghệ cao}

Sự kiện "hỏng hóc" tín dụng giai đoạn 1989 - 1990 đã cảnh tỉnh xã hội với rủi ro tài chính lần đầu tiên. Tuy vậy, tâm lý kỳ vọng thu lợi nhanh chóng từ các khoản cho vay có lãi suất cao dựa trên quan hệ cá nhân vẫn còn phổ biến. Đây cũng là mảnh đất cho các hoạt động lạm dụng lòng tin nhằm lừa gạt và chiếm đoạt tài sản. Thủ đoạn quen thuộc là tạo vẻ bề ngoài giàu có, kinh doanh phát đạt, có nhu cầu huy động vốn để đầu tư mở rộng và sẵn sàng trả lãi suất cao. Các khoản vay đầu tiên luôn được bảo đảm hoàn trả đầy đủ và đúng hạn cả gốc và lãi để tạo dựng uy tín. Bằng phương thức vay của người sau để trả cho người trước, mạng lưới sẽ được mở rộng nhanh chóng. Cuối cùng, với lượng lớn số tiền đã thu được, đối tượng tội phạm bỏ trốn để lại hàng trăm nghìn nạn nhân hoặc hơn thế, nếu ở quy mô nghiêm trọng. Bên cạnh thiệt hại kinh tế, sự bất ổn xã hội do loại tội phạm này tạo ra đã tăng lên rất đáng kể. Nạn nhân thường không có đầy đủ hiểu biết về kinh tế, pháp luật, số tiền cho vay hay góp vốn ngoài phần tiết kiệm tự có là đi huy động từ người thân, bạn bè. Cũng không thể bỏ qua hiệu ứng lâu dài là hệ quả tâm lý dây chuyền.

Trong nền kinh tế hiện đại cũng xuất hiện các hình thức lừa đảo tín dụng mới, khai thác đặc tính hiệu suất và lan tỏa của công nghệ thông tin. Vụ mạng "kinh doanh tiền tệ" Colony Invest cuối năm 2006 là một điển hình. Tự nhận là đại diện của công ty Colony Invest Management Inc tại Mỹ, một số đối tượng giới thiệu hình thức giao dịch đầu tư tài chính thông qua một số trang web như www.colonyinvest.net, www.callyinvest.com, www.money100.us, www.c-invest.com, www.vipviet.com. Theo quy định của đường dây này, nhà đầu tư trực tiếp đưa tiền cho người môi giới và được cấp một tài khoản, mật khẩu trên mạng. Một đô-la của nhà đầu tư, người môi giới được hưởng hoa hồng 0,02 USD. Quy tắc là, càng lôi kéo nhiều người tham gia, mức hoa hồng càng cao. Dữ liệu về số tiền đầu tư được hoán đổi thành điểm ảo. Người tham gia đầu tư, khi nộp tiền cho đại lý, không nhận được bất cứ giấy tờ nào, ngoài một tài khoản với những "điểm ảo" trên mạng, không được rút vốn gốc, chỉ được rút lãi. Những người tham gia mua bán "điểm ảo" với nhau. Con số nạn 
nhân ban đầu được ước tính chừng 5.000 người, nhưng ngay sau đó đã phát hiện phạm vi hoạt động hầu như toàn quốc của mạng lưới này. Số người liên quan thực tế có thể lên tới cả chục ngàn.

Trên hệ thống e-mail cũng xuất hiện hình thức lừa đảo qua thư đề nghị hợp tác hay trợ giúp thủ tục hưởng thừa kế, thông báo trúng giải thưởng có giá trị tới hàng triệu USD. Với đề nghị "hợp tác" nhận khoản tiền hấp dẫn, người nhận thư (con mồi của đối tượng) cần thu xếp trước một khoản kinh phí nhỏ và chuyển tới vị đại diện pháp lý nào đó để lo các thủ tục cần thiết; đôi khi thủ phạm lại không đòi hỏi kinh phí ngay từ ban đầu (để lấy lòng tin). Không lâu sau khi nạn nhân chuyển số tiền theo yêu cầu tới địa chỉ được chỉ dẫn, họ sẽ phát hiện ra là bị lừa. Interpol đã đưa hình thức lừa gạt này vào danh mục tội phạm tài chính quốc tế bởi mức độ phổ biến và tính chất xuyên quốc gia của hoạt động phạm tội với tên gọi "thư Ni-giê-ri-a"(1). Gần tương tự với hình thức này là đô-la đen. Đối tượng giả vờ có một số lượng lớn đô-la Mỹ đã được nhuộm đen để dễ dàng vận chuyển quốc tế, sau đó, mượn tiền của nạn nhân để mua hóa chất tẩy rửa với lời hứa sẽ chia một phần đáng kể trong tổng số tiền thu được. Dù đã rất quen thuộc từ cả chục năm, tới tận tháng 3-2008, báo chí Việt Nam đưa tin vẫn còn có những người trở thành nạn nhân của loại tội phạm này.

Các vụ lừa đảo tận dụng công nghệ cao thường phức tạp, tinh vi, khó phát hiện cũng như khó truy bắt. Con số nạn nhân thường đông đảo, phân bố trên phạm vi địa lý rộng khắp, nhất là trong tình huống có xuất hiện yếu tố nước ngoài, do vậy, dễ gây ra ảnh hưởng tâm lý tiêu cực trong xã hội. Trong quá trình hội nhập kinh tế toàn cầu và tự do hóa hoạt động của thị trường vốn, đây là vấn đề cần được đặc biệt quan tâm.

Việc thực hiện các giao dịch tài chính được tự động hóa ở mức độ ngày càng cao. Tận dụng khả năng công nghệ để thâm nhập vào các hệ thống quản trị tài chính, đánh cắp thông tin và tạo ra các giao dịch gian lận sẽ là nguy cơ cần sớm ngăn chặn. Theo cảnh báo năm 2007 của Trung tâm An ninh mạng (BKIS), 40\% trong tổng số 60 website của các công ty chứng khoán có lỗi về bảo mật, 140 website của các cơ quan, doanh nghiệp quan trọng tại Việt Nam tồn tại những lỗ hổng nguy hiểm có thể tạo điều kiện truy cập trái phép. Tuy nhiên, vấn đề này vẫn chưa nhận được quan tâm đúng mức. Khi bị xâm hại, hậu quả không đơn thuần dừng lại ở ngừng trệ, hoặc mất thông tin, dữ liệu trên website. Rủi ro tiềm ẩn là thông qua cánh cổng mở ra từ các website, tội phạm công nghệ có thể chiếm quyền vận hành hệ thống quản trị, từ đó, thực hiện các giao dịch gian lận với giá trị lớn.

\section{3 - Biến động nhanh và khó kiểm soát của thị trường tài chính}

Thị trường chứng khoán Việt Nam (TTCKVN) ra đời tháng 7-2000. Sau gần 8 năm vận hành, TTCKVN giúp huy động vốn gián tiếp quan trọng và hiệu quả, làm tăng đáng kể tính thanh khoản cho các tài sản tài chính của doanh nghiệp và Chính phủ. Nhưng quá trình phát triển nhanh chóng cả về thành phần và số lượng đối tượng tham gia, mức độ đa dạng các sản phẩm, lẫn tính phức tạp tăng lên trong cơ chế giao dịch, vận hành, và kiểm soát thị trường... cũng phát sinh những vấn đề cần lưu ý, vì gây ra rủi ro tiềm tàng ở quy mô rất lớn, có thể là toàn xã hội. 
Sau hai năm đầu tăng trưởng khó khăn, TTCKVN rơi vào một thời kỳ trầm lắng kéo dài (2002 2005); với mức quan tâm của xã hội dành cho TTCK hầu như không đáng kể. Mãi tới nửa cuối năm 2006, sự sôi động mới thực sự xuất hiện, thể hiện qua các thống kê thị trường.

Nếu như giai đoạn 2002 - 2004, TTCK chỉ xuất hiện thêm một số lượng khiêm tốn là 6 mã cổ phiếu, thì năm 2005, số cổ phiếu niêm yết tăng lên 41. Và con số này chưa bằng \# số lẻ của tổng số cổ phiếu niêm yết trên TTCK năm 2006 là 187. Riêng năm 2006, đã có 146 cổ phiếu niêm yết mới, gấp hơn ba lần số tích lũy trong suốt thời kỳ 2000 - 2005. Tính đến hết năm 2007, có 250 mã cổ phiếu được niêm yết và tới 11-4-2008, con số đó là 286.

Thị trường chứng khoán Việt Nam nhộn nhịp hơn với hệ thống trung gian tài chính gồm 87 CTCK và 30 công ty quản lý quỹ, thu hút đông đảo các nhà đầu tư trong nước và quốc tế, với xấp xỉ 298.000 tài khoản vào cuối 2007 , trong đó có trên 7.000 là của nhà đầu tư nước ngoài, tăng gần $300 \%$ so với năm trước (2006: 106.000).

Sự "hưng phấn" của TTCK được thể hiện qua xu thế tăng mạnh của VN-Index từ cuối 2006 đến nửa đầu 2007. Khi chỉ số thị trường đều đặn cộng thêm 5\% vào sau mỗi phiên giao dịch, niềm tin về sự tồn tại một "cỗ máy tạo tiền" hình thành và hối thúc người người, nhà nhà bỏ vốn vào chứng khoán. Một suy nghĩ rất đơn giản và phổ biến cho rằng: "chơi" chứng khoán là một hình thức tiết kiệm lãi suất cao. Thị trường chiều lòng người. Các đỉnh cao kỷ lục VN-Index liên tục bị phá vỡ. Ngày 1-12-2006, VN-Index ở mức 631. Mười chín ngày sau, VN-Index đạt kỷ lục 810. Đầu năm 2007, VN-Index được ghivới bốn chữ số. Liên tục tháng hai, ba và cả nửa đầu tháng tư, chỉ số chung của thị trường ở trên mức 1.000. Đỉnh cao nhất của VN-Index là 1.171 điểm (12-3-2007).

Nhưng sự sụt giảm cũng diễn ra rất mau chóng. TTCKVN suy giảm còn nhanh và mạnh hơn lúc tăng trưởng. Nửa cuối 2007 cho thấy TTCKVN phổ biến ở 2 trạng thái, hoặc đi xuống hoặc hầu như không tăng. Kể từ đầu 2008 thì thực sự bước vào giai đoạn sụt giảm mạnh, liên tục. VN-Index lùi về mức 496,6 điểm vào ngày 25-3-2008. (Bảng 1).

Bảng 1: Xác lập mức "đáy" của VN-Index

\begin{tabular}{|l|c|c|}
\hline Ngày & Mức “đáy” & VN-Index \\
\hline $7-1-2008$ & 900 & 887 \\
\hline $23-1-2008$ & 800 & 776 \\
\hline $26-2-2008$ & 700 & 692 \\
\hline $5-3-2008$ & 600 & 583 \\
\hline $25-3-2008$ & 500 & 497 \\
\hline
\end{tabular}

Nguồn: www.asset.vn 
Biến động mạnh và nhanh của TTCK gây tác động tâm lý tiêu cực cho đại đa số người tham gia thị trường, đặc biệt với các nhà đầu tư nhỏ lẻ. Khi thị trường ở vào đỉnh cao, số tiền tích lũy của một cá nhân trở nên không đủ lớn để tìm kiếm mức lợi nhuận đáng kể từ kinh doanh chứng khoán thì xuất hiện từng nhóm cá nhân cùng nhau góp vốn, huy động cá nhân, vay ngân hàng để có số vốn đáng kể tham gia thị trường. Bởi vậy, khi giá cổ phiếu đồng loạt đi xuống, áp lực thu hồi vốn, thanh toán nghĩa vụ tín dụng đè nặng lên đám đông với quy mô lớn hơn nhiều lần số tài khoản giao dịch chứng khoán thống kê được.

Suy giảm trong 3 tháng đầu năm 2008 đưa TTCKVN về vạch xuất phát của năm 2006 (xem hình trên). Các phản ứng tiêu cực và thái quá của số đông công chúng đầu tư hoàn toàn có thể hiểu được, nhưng đó cũng chính là những dấu hiệu bất ổn cần đặc biệt lưu tâm, kèm theo các xung đột và tranh chấp lợi ích tài chính tiềm tàng, gay gắt và ở quy mô rộng lớn hơn trong thời gian tới.

Ngày 5-3-2008, một nhóm các nhà đầu tư đã có mặt tại TTGDCK Hà Nội đề nghị đóng cửa thị trường, ngừng giao dịch. Tiếp sau đó, khi biết lãnh đạo UBCKNN đang có buổi họp báo cùng các cơ quan truyền thông, nhà đầu tư đã đến và yêu cầu giải thích lý do giá chứng khoán sụt giảm. Tham gia giao dịch chứng khoán với hành trang kiến thức thiếu đầy đủ chính là căn nguyên của những ngộ nhận về tiềm năng và rủi ro trên TTCK, cũng như những yêu cầu phi thị trường khi đòi hỏi cơ quan nhà nước đứng ra bảo vệ và có các động thái tác động để giá cổ phiếu không giảm, thậm chí là tăng lên.

\section{4 - Xung đột lọii ích trong hoạt động kinh tế - kinh doanh - tài chính}

Trong nền kinh tế thị trường, mọi tác nhân đều theo đuổi lợi ích riêng và một "bàn tay vô hình" của thị trường bảo đảm mục tiêu này sẽ được chuyển thành hiệu quả tối ưu và tạo ra của cải với hàng hóa thông thường. ở mức độ cơ bản nhất, tại doanh nghiệp, xung đột lợi ích phát sinh khi xuất hiện nhà đầu tư bên ngoài muốn tham gia điều khiển theo cách thức khác với những nhà quản lý hiện tại. Sự phân tán trong quyền sở hữu góp phần khuếch đại vấn đề này. Nó làm gia tăng các mâu thuẫn quyền lợi giữa những người cùng chia sẻ lợi ích từ doanh nghiệp và kích thích những hành động vì lợi ích cá nhân của nhà đầu tư.

Những công ty không do chính chủ sở hữu quản lý dễ gặp phải bất ổn về tổ chức: những người quản lý công ty được yêu cầu đặt lợi ích của công ty cao hơn lợi ích của chính họ và hai lợi ích này có thể không gặp nhau. Đây là điều các nhà kinh tế học thường gọi bằng tên "vấn đề đại diện": người quản lý công ty là người đại diện cho chủ sở hữu và khi lợi ích của người đại diện này được ưu tiên trên hết, lợi ích thực sự của công ty sẽ bị đe dọa. Ngay cả khi cổ đông có thể kiểm soát hay tham gia trực tiếp quản lý công ty thì vẫn tồn tại xung đột lợi ích giữa những cổ đông quản lý với nhóm còn lại. Với nền kinh tế đang trong giai đoạn chuyển đổi như Việt Nam, mô hình phổ biến là người chủ doanh nghiệp - người sáng lập nắm quyền sở hữu hầu như toàn bộ doanh nghiệp, tiếp tục đóng vai đại cổ đông và người điều hành sau quá trình đại chúng hóa doanh nghiệp.

Khi doanh nghiệp có người điều hành là cổ đông nắm giữ toàn bộ hoặc có phần sở hữu rất lớn thì 
vấn đề xung đột lợi ích hiếm khi xảy ra. Đơn giản vì nếu có một quyết định bất lợi cho công ty, người ra quyết định tự gây thiệt hại cho mình. Mọi rắc rối nảy sinh khi cổ đông lớn nắm quyền kiểm soát và/hoặc điều hành doanh nghiệp khi chỉ nắm giữ $51 \%$ cổ phần hay thậm chí ít hơn. Nếu cổ đông này đi ngược lại lợi ích của công ty, bản thân họ chỉ phải chịu thiệt hại theo tỷ lệ phần trăm sở hữu. Đặc biệt, trong trường hợp cấu trúc tài chính kiểu kim tự tháp hoặc cổ phiếu có quyền ưu đãi quyết định, khi phần trăm kiểm soát vượt quá tỷ lệ sở hữu thì vấn đề xung đột lợi ích càng dễ trở nên trầm trọng.

Thế giới đã chứng kiến nhiều bài học về xung đột lợi ích. Trong quá trình tư nhân hóa tại Nga, những người điều hành đã bán lại với giá thấp tài sản của doanh nghiệp, gây thất thoát không nhỏ cho nhà nước. Điều tương tự cũng xảy ra với với các Chaebol của Hàn Quốc, khi nhiều vị lãnh đạo cao cấp bán lại các đơn vị thành viên hay cung cấp sản phẩm với nhiều điều kiện ưu đãi cho những người thân cận. Trên thị trường tài chính, gian lận của đội ngũ điều hành Livedoor (Nhật Bản) và Enron (Hoa Kỳ) đã dẫn tới thiệt hại nghiêm trọng của các cổ đông và đưa doanh nghiệp tới kết cục tồi tệ nhất: đóng cửa. Ngay tại Việt Nam, không phải thị trường chưa từng có kinh nghiệm với các sự vụ tương tự.

Trong lịch sử TTCKVN, sự kiện kết thúc quý I năm 2003, Bibica đã vài lần xin hoãn nộp báo cáo quyết toán, cho mãi đến tháng 5-2003 khi sự thật bị phơi bày, Bibica thông báo mức lỗ năm 2002 là 2,7 tỉ đồng, rồi ngay lập tức sửa thành 5,4 tỉ đồng trong một buổi họp sau đó vài ngày. Nhưng báo cáo độc lập của Ban Kiểm soát trong Đại hội cổ đông năm 2003 lại bác bỏ số lỗ 5,4 tỉ đồng do Ban Giám đốc công bố, và đưa ra số lỗ thực 12,7 tỉ đồng. Trong vòng 6 tháng sau đó, giá cổ phiếu $\mathrm{BBC}$ mất hơn $50 \%$, kèm theo nhiều nhân sự chủ chốt của phòng kế toán Bibica ra đi. Kết quả kiểm toán lần thứ hai đối với báo cáo tài chính năm 2002 cho thấy có sự "xào nấu" sổ sách kế toán và mức lỗ thực của Bibica đúng như số liệu của Ban kiểm soát. Ngoài ra, công ty kiểm toán cho biết họ đã cùng Bibica lập lại một bản quyết toán của tài khóa 2002 trước khi kiểm toán. Theo bản quyết toán lần đầu do các nhân sự cũ của phòng kế toán lập, Bibica đạt lợi nhuận 8,9 tỉ đồng trong năm 2002. Như vậy, tổng cộng số tiền mà cựu kế toán trưởng Bibica "chế biến" được sau khi "xào nấu" sổ sách xấp xỉ 20 tỉ đồng.

Một ví dụ khác, Công ty Đồ hộp Hạ Long (Canfoco) từng bị ngừng giao dịch vào ngày 8-10-2002 sau khi ba nhân viên công ty bị khởi tố làm khống chứng từ, chiếm đoạt 7 tỉ đồng tiền VAT. Từ ngày 16-10-2002, khi bắt đầu được giao dịch trở lại, cho đến ngày 20-11-2002, CAN chỉ có 3 ngày tăng nhẹ, còn lại là giữ giá và giảm giá. Theo điều tra, hơn 100 tỉ đồng doanh thu của CAN tạo ra trong năm 2001 là con số ảo.

Đó là những gì xảy ra trong quãng thời gian TTCK kém sôi động hơn hai năm vừa qua rất nhiều. Ngoài việc xuất hiện hàng trăm mã cổ phiếu mới, việc phát hành cổ phiếu bổ sung tăng vốn điều lệ, mở rộng quy mô sản xuất, kinh doanh, phát triển dự án mới cũng được thực hiện phổ biến và khẩn trương. Nếu chỉ nhìn riêng vào diễn biến VN-Index năm 2007, có thể thấy ngay rằng, trung bình mỗi đồng cổ phiếu phát hành sẽ thu về lượng thặng dư vốn 5 - 6 đồng không mấy khó khăn. Và đó 
là nguồn động lực không nhỏ thúc đẩy các doanh nghiệp cũng như những người điều hành đang nắm giữ một lượng tương đối lớn cổ phiếu của doanh nghiệp. Làn sóng thành lập công ty bất động sản, công ty chứng khoán, ngân hàng, công ty tài chính - đầu tư xuất hiện và liên tiếp dâng cao. Đây đều là các lĩnh vực kinh doanh rất hấp dẫn, hứa hẹn lợi nhuận tốt và chia sẻ các đặc điểm: quy mô vốn lớn (từ vài chục tới vài trăm hay vài nghìn tỉ), thời gian để các tiềm năng chuyển thành giá trị thật từ 3 - 5 năm, ngành mới - các đơn vị sáng lập không có nhiều kinh nghiệm hoạt động. Nói cách khác, tính khả thi và hiệu quả của các dự án mới dừng lại ở các cơ hội trong tương lai và chưa được kiểm chứng.

Công ty Cổ phần Địa ốc Sài Gòn Thương tín (Sacomreal) được thành lập tháng 3-2004, với vốn điều lệ 10 tỉ đồng. Cuối năm 2005, Sacomreal nâng mức vốn điều lệ lên 33 tỉ đồng. Từ giữa năm 2006, quy mô vốn điều lệ của công ty bắt đầu mở rộng nhanh chóng. Tháng 7-2006, công ty đăng ký mức vốn điều lệ 100 tỉ. Nửa năm sau, mức này được bổ sung thêm 100 tỉ. Đến đầu quí II năm 2007, Sacomreal có vốn điều lệ 320 tỉ. Ngày 1-6-2007, công ty đăng ký vốn điều lệ 505 tỉ (gấp 5 lần một năm trước đó). Có thể thấy rằng, mở rộng quy mô hoạt động kinh doanh gấp 5 lần trong thời gian 12 tháng là một thành tích đáng nể. Thử định giá cổ phiếu Sacomreal ở mức khiêm tốn là 30.000 đ/cổ phiếu (mệnh giá: 10.000 đ/cổ phiếu) thì phần thặng dư vốn thu được tính cho phần chênh lệch vốn điều lệ giữa năm 2006 và năm 2007 sẽ vào khoảng 400 tỉ x (3-1) lần = 800 tỉ. Cho dù ngành bất động sản có mức tỉ suất lợi nhuận cao thế nào, cũng rất khó hình dung một công nghệ kinh doanh mang lại mức lợi suất trên $150 \%$ trong 12 tháng nhanh và dễ như vậy.

Bảng: Lịch sử thay đổi vốn điều lệ của CTCP Địa ốc Sài Gòn Thương Tín

\begin{tabular}{|l|r|r|}
\hline Ngày thay đổi & \multicolumn{1}{|c|}{ Giá trị thay đổi } & \multicolumn{1}{|l|}{ Vốn sau thay đổi } \\
\hline $1-6-2007$ & 185.000 .000 .000 & 505.000 .000 .000 \\
\hline $1-4-2007$ & 120.000 .000 .000 & 320.000 .000 .000 \\
\hline $1-1-2007$ & 100.000 .000 .000 & 200.000 .000 .000 \\
\hline $01-07-2006$ & 67.000 .000 .000 & 100.000 .000 .000 \\
\hline $01-11-2005$ & 22.000 .000 .000 & 33.000 .000 .000 \\
\hline $01-03-2004$ & & 11.000 .000 .000 \\
\hline
\end{tabular}

Nguồn: www.asset.vn - Đơn vị: đồng

Khi các doanh nghiệp niêm yết tận dụng sức hấp dẫn của TTCK để thu hút nguồn lực xã hội, khả năng sử dụng đồng vốn ở mức hiệu quả thấp rất dễ xảy ra. Tình hình sẽ nghiêm trọng hơn, khi mà nguồn vốn từ huy động không bổ sung năng lực kinh doanh, tăng sức cạnh tranh của doanh nghiệp. Đồng thời, một phần của nguồn vốn đó chuyển thành tài sản cá nhân của nhóm các cổ đông vốn sở 
hữu lượng cổ phần lớn trong công ty thoái vốn để thu hồi tài sản tiền mặt cá nhân. Việc giảm nhanh tỷ lệ sở hữu của các vị trí lãnh đạo chủ chốt, đặc biệt khi cổ phiếu ở mức giá cao, làm trầm trọng thêm nguy cơ xung đột lợi ích giữa các nhóm cổ đông. Dư luận đặc biệt quan tâm mức cổ tức tiền mặt tại mùa đại hội cổ đông đầu 2008 phần nào cũng là biểu hiện sự lo lắng và mâu thuẫn giữa lợi ích đầu tư tài chính ngắn hạn với nhà đầu tư gắn bó lâu dài của doanh nghiệp. Một mối nguy khác là, toàn bộ cỗ máy kinh doanh ngừng trệ hoặc suy giảm hiệu quả do chạy theo các hoạt động tài chính, quan hệ nhà đầu tư, phát hành và chuyển nhượng cổ phiếu...

\section{5 - Tăng tính dễ bị tổn thương của hệ thống tài chính quốc gia với các vận động kinh tế và dòng vốn quốc tế}

Với hệ thống chính trị ổn định, vị thế tăng cao qua quá trình quốc tế hóa đời sống kinh tế, kết quả tăng trưởng kinh tế tích cực, Việt Nam được xem là điểm đầu tư hấp dẫn của thế giới giai đoạn 2005 - 2008. Năm 2007, vốn FDI vào Việt Nam đạt kỷ lục 20,3 tỉ USD, tăng 69,1\% so với năm 2006 và vượt 56\% so với dự kiến. Trong ba tháng đầu năm 2008, vốn FDI đăng ký vào Việt Nam trên 5,4 tỉ USD. Theo Cục Đầu tư nước ngoài, mức vốn này tăng hơn $30 \%$ so với cùng kỳ năm 2007.

Thị trường tài chính ghi nhận sự quay trở lại của các quỹ đầu tư nước ngoài. Có mặt tại Việt Nam khá sớm từ đầu những năm 90 của thế kỷ trước, tám quỹ đầu tư nước ngoài với quy mô vốn khoảng 700 triệu USD lần lượt rút lui sau khủng hoảng tài chính - tiền tệ châu á năm 1997. Thời điểm sau năm 1997, chỉ còn lại hai quỹ Vietnam Enterprise Investment Limited (VEIL) do công ty Dragon Capital quản lý và Vietnam Frontier Fund (VFF) thuộc tập đoàn Finasa. Bản thân VFF, quy mô vốn 50 triệu USD, sau đó cũng rời khỏi Việt Nam. Giai đoạn 2002 - 2005, mặc dù TTCK tương đối trầm lặng, vẫn xuất hiện thêm nhiều quỹ mới thuộc các công ty Mekong Capital, VinaCapital, VietFund hay PXP Asset Management. Vào thời kỳ bùng nổ của TTCK, cùng với sự xuất hiện của vài chục công ty quản lý quỹ Việt Nam, các dòng tài chính nước ngoài cũng "lũ lượt" vào Việt Nam.

http://www.saga.vn/: Tháo chạy vốn (capi-tal flight) là sự dịch chuyển nguồn tiền đầu tư từ khu vực hiện tại sang khu vực mới nhằm tìm kiếm mức độ ổn định cao hơn hoặc gia tăng mức lợi nhuận đầu tư thu được. Quá trình tháo chạy vốn ghi nhận dòng vốn đầu tư nước ngoài rất lớn được chuyển ra khỏi quốc gia, thường trong các khoảng thời gian mà thị trường tiền tệ gặp nhiều vấn đề bất ổn. Quy mô của lượng vốn tháo chạy này cũng thường lớn tới mức đủ để gây tác động cho toàn bộ hệ thống tài chính quốc gia.
Thời điểm giữa năm 2006, VinaCapital khai trương quỹ đầu tư bất động sản Vinaland với dự kiến huy động 50 triệu USD nhưng đã nhận được 65 triệu từ các nhà đầu tư. Thành công trong lần phát hành và niêm yết trên thị trường chứng khoán London của Indochina Capital Vietnam Holiding Limited thể hiện tính sẵn sàng của dòng vốn quốc tế cho Việt Nam và là một bất ngờ. Trong lần phát hành này, Indochina Capital dự kiến thu hút từ 300 - 350 triệu USD, kết quả, tổng số vốn huy động được là 500 triệu USD. Số tiền 50 triệu USD còn lại trong quỹ Vietnam Opportunities Fund (VOF) cũng được VinaCapital nỗ lực giải ngân tập trung trên thị 
trường địa ốc và các giao dịch OTC. Mekong Capital mở rộng quy mô với 50 triệu USD cho MEFII (Mekong Enterprise Fund II). Indochina Capital góp mặt với quỹ địa ốc 42 triệu USD và quỹ chứng khoán quy mô 50 triệu USD. Ngoài ra, còn phải kể tới quỹ đầu tư của các tập đoàn bảo hiểm quốc tế tại Việt Nam như Prudential Vietnam hay Manulife Vietnam với mức vốn đăng ký vài chục triệu USD.

Sự góp mặt của các tên tuổi tài chính quốc tế như Merrill Lynch, Goldman Sachs, JP Morgan cùng lực lượng hùng hậu các quỹ đầu tư nước ngoài tại Việt Nam là tín hiệu đáng phấn khởi. Dẫu vậy, tác động không nhỏ của các lực lượng này lên thị trường tài chính Việt Nam không thể bỏ qua. Trong lộ trình hội nhập WTO, thị trường vốn Việt Nam tiến dần tới chỗ tự do hoàn toàn. Đã có 37 chi nhánh ngân hàng nước ngoài hoạt động tại Việt Nam, sắp tới sẽ là sự xuất hiện của ngân hàng thương mại, công ty chứng khoán, công ty bảo hiểm 100\% vốn nước ngoài, các rào cản với dịch chuyển vốn quốc tế cũng sẽ dần được gỡ bỏ. Khi đó, từng biến động của thị trường tài chính thế giới và khu vực sẽ gây ảnh hưởng trực tiếp tới hệ thống tài chính Việt Nam. Hiện tượng tháo chạy vốn khi xuất hiện các biến cố tài chính, như đã từng xảy ra với Ma-lai-xi-a hay Thái Lan vào năm 1997 - 1998, hoàn toàn có thể lặp lại với Việt Nam. Hệ lụy của việc dòng vốn đầu tư nước ngoài đột ngột rút đi sẽ càng nghiêm trọng khi năng lực sản xuất và cạnh tranh nội tại của nền kinh tế chưa có đủ thời gian cần thiết để cải thiện. Lúc này, các đối tác Việt Nam mới chỉ kịp hoàn thành nghĩa vụ đối ứng bằng việc đóng góp và chuẩn bị hạ tầng, nhà xưởng và mở rộng tiêu dùng mua sắm máy móc, thiết bị.

Ngoài ra, nếu có thể thực hiện một phép cộng gộp lượng tài sản mà nhóm quỹ đầu tư nước ngoài đang nắm giữ thì sẽ được một con số ngang bằng với tỷ lệ không nhỏ của GDP. Một lực lượng kinh tế nước ngoài có ảnh hưởng ngày một mở rộng đang được hình thành.

\section{6 - Khoảng cách giữa cấu trúc vĩ mô và triển khai vi mô}

Trong nền kinh tế, hệ thống tài chính được điều hành bởi các chính sách vĩ mô và thực thi tại cấp vi mô, cụ thể tới đơn vị doanh nghiệp. Hiện nay vẫn tồn tại tình trạng không đồng bộ giữa hai cấp điều hành và thực thi. Chính sách vĩ mô dù có đúng đắn tới đâu cũng cần được thi hành đầy đủ mới mang lại hiệu quả mong muốn. Khi chưa nắm vững phương thức triển khai ở cấp độ vi mô, người hoạch định chính sách ở vào tình thế bị động, không lường trước được các phản ứng và hệ quả của việc thực thi chính sách. Kết quả thực thi chỉ tới khi đã hiển hiện mới được ghi nhận. Và nếu không phải là kết cục mong đợi thì hành động tiếp theo của những người làm chính sách là điều chỉnh quyết sách mới được đưa ra. Cách làm này, nếu kéo dài, tạo tâm lý bất an đối với hành lang pháp lý điều khiển các hoạt động kinh tế.

Trong những tháng qua, khi thị trường chứng khoán suy giảm, giá cả tăng cao, lãi suất của các ngân hàng thương mại bị đẩy lên mức kỷ lục, Chính phủ đã thực hiện đồng bộ nhiều chính sách thực hành tiết kiệm, khuyến nghị các doanh nghiệp hạn chế phát hành mới, huy động vốn bổ sung và rà soát lại tính khả thi và hiệu quả của các dự án. Tuy vậy, việc dừng ngay các dự án đang triển khai là rất khó khăn với doanh nghiệp. Bởi kèm theo đó là những cam kết sẽ phải hủy bỏ với đối tác, nhà 
cung cấp, khách hàng, là các khoản đã đầu tư vào máy móc, thiết bị, nhà xưởng, mặt bằng... phải trở thành chi phí treo, chưa nói tới tính nghiêm trọng của hàng loạt lao động cũng bị cuốn mất theo "tiếng còi" dừng cuộc chơi này. Còn phải kể tới sức hấp dẫn của khoản thặng dư vốn cổ phần sau mỗi đợt phát hành mới. Dù rằng con số thu được chỉ bằng một nửa so với lúc TTCK tăng trưởng cao thì việc thu hút và tích lũy một lượng tiền mặt để dự phòng các biến cố kinh tế có thể xảy đến cũng đủ tạo động lực cho doanh nghiệp.

\section{7 - Hạn chế trong thực hành truyền thông tài chính}

Chất lượng của hệ thống truyền thông tài chính ở Việt Nam cũng là điều đáng bàn, và đã tiềm tàng những rủi ro sinh ra từ một (hay hơn) trong ba nhân tố cấu thành chất lượng: Giá trị thông tin, quá trình phân tích và phương tiện thực hành truyền thông.

Bằng chứng về sự "hào hứng" của xã hội và số lượng ấn phẩm tham gia vào truyền thông tài chính không hề tỷ lệ thuận với chất lượng truyền thông ở Việt Nam, do yếu tố xung đột, nguồn, chất lượng cung cấp, sự bảo đảm khách quan và hiệu quả của phương tiện, vẫn chưa được kiểm soát gắt gao. Trên TTCK, giá chứng khoán có thể tăng giảm theo các dòng thông tin. Nhưng việc tăng giảm này chỉ đồng nghĩa với việc "xác lập được điểm cân bằng" khi và chỉ khi các quy tắc văn minh được bảo đảm, điều này hiện không ai dám khẳng định.

Rõ ràng, thông tin là một giá trị và quyền sở hữu, quyền ngăn chặn người khác tiếp cận thông tin chính xác đã trở thành một thứ quyền lực ghê gớm. Tính chất "giá trị" của nội dung thông tin đã được khẳng định ngày càng rõ, cho dù có tuân theo ý đồ của người đưa tin hay không. Chính vì thế, sự công bằng thông tin phải trở thành một chuẩn mực, mà nếu không được bảo đảm, rủi ro sẽ thành biến cố chắc chắn, một khi bối cảnh phù hợp xuất hiện.

* Thiếu tướng, Tổng Cục 5, Bộ Công an

** Tiến sĩ, Đại học Tổng hợp Bruxelles (Bỉ)

(1) Do ban đầu các lá thư giả mạo thường được gửi đi với xuất xứ từ Ni-giê-ri-a

Phạm Minh Chính* Vương Quân Hoàng** 